\title{
Nutritional, Functional Role of Kodo Millet and its Processing: A Review
}

\author{
Durga Shankar Bunkar ${ }^{1 *}$, S K Goyal ${ }^{2}$, Kamalesh Kumar Meena ${ }^{3}$ and \\ Virendra Kamalvanshi ${ }^{4}$
}

${ }^{1}$ Department of Dairy Science and Food Technology, BHU, Varanasi (U.P.), India

${ }^{2}$ Department of Agricultural Engineering, BHU, Varanasi (U.P.), India

${ }^{3}$ Department of Dairy and Food Microbiology, CDFT, MPUAT, Udaipur (Raj.), India

${ }^{4}$ Department of Agricultural Economics, BHU, Varanasi (U.P.), India

*Corresponding author

\section{A B S T R A C T}

Keywords

Kodo millet, Health benefit, Nutritional properties, Millet processing

\section{Article Info}

Accepted:

12 December 2020

Available Online:

10 January 2021
Kodo millets do not contain gluten and are useful for individuals who are intolerant to gluten. Kodo millet is very easy to digest due to higher amount of lecithin, which is good for functioning of the nervous system. Regular use of Kodo millet is very useful for postmenopausal females with indications of cardiovascular disease such as high blood pressure and high level of cholesterol. It includes higher amount of antioxidants that help against oxidative stress and maintain glucose concentrations in type-2 diabetes. Kodo millet is useful in curing asthma, migraine, blood pressure, heart attack and atherosclerosis, diabetic heart disease. So, research on production of millet based products is emerging area to utilize its beneficial effect considering increasing population in developing countries.

\section{Introduction}

Millets are forage grasses which belong to family Poaceae. Millets are one of the cereals asides the major wheat, rice, and maize. These are key agriculture produce on a global level having significant contribution for the people having low income especially in developing countries. Millets can be grown in a short period, can sustain drought condition crop and have long storage period without insect damage (Adekunle, 2012). They are small to medium size crops that are cultivated throughout the tropics and subtropical region. The millets belonging to genus Poaceae (true grass) can be classified as major millets and minor millets which are cultivated in India, China, Malaysia, Srilanka, Australia and some parts of Africa since ancient times (Baltensperger, 1996). The major millets are Pearl millet (Pennisetum glaucum), Foxtail millet (Setaria italica), Proso millet or white 
millet (Panicum miliaceum), and Finger Millet (Eleusinecoracana). Minor millets includes Barnyard millet (Echinochloa spp.), Kodo millet (Paspalum scrobiculatum), little millet (Panicum sumatrense), Guinea millet (Brachiaria deflexa), and Browntop millet (Urochloa ramose/Brachiaria ramosel Panicum ramosum) (Chinchole et al., 2017; ICRISAT, 2017; Yang et al., 2012, Nithiyanantham et al., 2019). Millets are small annual grains of cereals seed. These plants are very hardy and can be effectively cultivated in lands of infertility. Diseases and pests are less susceptible to these plants. It is stable like wheat and rice. Some of them exceed the average protein, fat and mineral content (Gopalan and Shastri, 2009). All the millets are rich in calcium, iron, folic acid, niacin, potassium, magnesium and zinc (Parvathy and Thayumanavan, 1995).

Coarse cereals are primarily used as animal feed in advanced nations, whereas $68-98 \%$ of coarse cereals are used for human consumption in developing nations. Depending on the taste and cultural preferences, they are placed to many uses in our diet. Millets are currently produced in Northern China, India, Africa and Southern Russia, with about $80 \%$ of the crop being consumed directly as food (Sindhu and Khetarpaul, 2001). The word "millet" applies to different plants of grass whose seeds are harvested for human consumption or animal feed (Crawford and Lee, 2003). Compared to other cereal grains, millet production in India is very small. Throughout the year, minor millets such as foxtail, Kodo and small millets are readily accessible. It is cheaper than other significant millets and cereals. Millets are especially low in phytic acid and high in dietary fiber, iron, calcium and B-vitamins. It also includes greater proportions of unavailable carbohydrates. Due to poverty, moving consumption patterns from a balanced diet, extensive incidence of nutritional deficiencies and also low consumption of nutritious cereals, nutritional deficiencies have decreased considerably over the previous three decades (Malathi et al., 2012). The growing population of world needs food which is a great challenge for governments and policy makers. Therefore, it is important to explore plants such as millets that are grown locally and consumed by low income households in places like India and the Sahel zone (Obiana, 2003). Cereals especially millet based foods and beverages are used throughout the world and are still part of the major diet in most African countries (Obilana and Manyasa, 2002; Amadou et al., 2013). The present review summarizes the nutritional composition of Kodo millets, some health benefits, and the use of it in the food industry.

\section{History of Origin and Distribution of Kodo millet}

India is known as the country where Kodo millet was originated. It is assumed that domestication of Araka or Kodo millet (Paspalum scrobiculatum L.) was took place about 3000 years ago (House et al., 1995; Arendt and Dal, 2011). The tropical and subtropical regions are best suited for its cultivation (Hulse, 1980; Saxena et al., 2018). It is grown on poor soils and it is widely distributed in arid and semi-arid regions of India an African Countries. In India, it is a small grain crop and a significant crop in the plateau of Deccan. In India, its cultivation is usually limited to Gujarat, Karnataka, Chhattisgarh, Eastern Madhya Pradesh and parts of Tamil Nadu. It is an annual grass species that grows to around $90 \mathrm{~cm}$ height. The Kodo millet grain color varies from light red to dark grey which is bounded in a tough husk that is difficult to remove. In latest years, millets have been acknowledged as significant replacements for main cereals in order to deal with global food shortages and satisfy the demand from developing and 
developed nations for a growing population. Kodo millet is categorized as coarse grain and is mainly grown in India, China, Russia, Japan and Africa. Kodo grains are readily maintained and demonstrated to be a good reserve for starvation. Kodo grains comprise protein $8.35 \%$, fat $1.45 \%$, carbohydrate $65.65 \%$ and ash $2.95 \%$. It can be regarded a cereal-nutrient. Kodo millet belongs to the Poaceae family and is also known as cow grass, ditch millet. Kodo millet is cultivated mainly in India and Madhya Pradesh ranks first in its cultivation in the country. It contributes about $50 \%$ area and $35 \%$ production of total millet in the country (Bhat et al., 2017; Balasubramanian, 2013; Devi et al., 2014). It is monocot crop and smaller size seeds, $1.5 \mathrm{~mm}$ in width, $2 \mathrm{~mm}$ in length and light brown to dark gray in color and it is covered in a husk which is hard to remove (Nithiyanantham et al., 2019). Kodo millet is well known for the highest drought resistance among all minor millets and said to produce good yield with in less growing period i.e. 80-135 days (Ravi, 2004, Saxena et al., 2018).

\section{Nutritional parameters of Kodo millet}

Millets are unique among the cereals because of their richness in calcium, dietary fibre, polyphenols and protein (Devi et al., 2011). Millets are good sources of magnesium and phosphorus. Magnesium has the ability to help reduce the effects of migraine and heart attacks, while, phosphorus is an essential component of adenosine triphosphate (ATP) a precursor to energy in the body (Badau et al., 2005; Liang et al., 2010; Devi et al., 2011). Kodo millet is rich in vitamins, minerals, and phytochemicals containing sulfur, so it is called "nutria-cereals"It is also rich in essential amino acids, like lysine, threonine, valine, sulphur containing amino acids and the ratio of leucine to isoleucine is about 2.0 (Ravindran, 1992; Antony et al., 1996), but it is deficient in tryptophan amino acid. Kodo millets are rich in vitamin $\mathrm{B}_{3}$, vitamin $\mathrm{B}_{6}$ and folic acid as well as minerals such as calcium, potassium, magnesium and zinc. Kodo millet grain contains 8.3 per cent protein in which major protein is glutelin (Sudharshana et al., 1988). It contains high amount of crude fiber $(9 \%)$ as compared to wheat $(1.2 \%)$. It provides $353 \mathrm{Kcal}$ energy per for $100 \mathrm{gm}$ of grain. Kodo millet contains $66.6 \%$ carbohydrate, $2.4 \%$ minerals, $1.4 \%$ fat and $2 \%$ ash. The range of iron content in Kodo millet is $25.86 \mathrm{ppm}$ to $39.60 \mathrm{ppm}$ (Chandel et al., 2014). The overall average nutrient composition of Kodo millet is given below in table 1 .

\section{Phytochemical Composition of Kodo millets}

It is well known that millets are rich source of bioactive compounds as well as with potential functional properties (Okwudili et al., 2017). Millets grains are good sources of polyphenols (Chethan, 2008). The important group of phenolic compounds are gallic acid, tannins, gentisic acid, protocatechuic acid, caffeic acid, vanillic acid, syringic acid, ferulic acid, para coumaric acid, transcinnamic acid, and 5- n-alkyl-resorcinols which are found in all types of millet grains (Bellato et al., 2013; Pradeep and Sreerama, 2018; Nithiyanantham et al., 2019). Many phenolic compounds have the properties to scavenge free radicals and reduce ROs which leads to prevent and treat the disease caused by free radicals (Chandrasekara and Shahid 2011; Nithiyanantham et al., 2019).

Kodo millet has $32.39 \pm 0.93$ ( $\mu$ mol of ferulic acid equiv/g of defatted meal) soluble phenolic content. Its bound phenolic content is around $81.64 \pm 0.15 \mu \mathrm{mol}$ of ferulic acid equiv/g of defatted meal was $81.64 \pm 0.15$ (Chandrasekara and Shahid 2011).

Flavonoids are considered major polyphenolic 
component in the millets. The important polyphenols which are present in millets are catechin, orientin, iso-orientin, quercetin, luteolin, apigenin, vitexin, myricetin, isovitexin, daidzein, sponarin, violanthin, lucenin- 1, and tricin (Chandrasekara and Shahidi, 2011; Pradeep, and Sreerama, 2015). The various research groups have proved that millet flavonoids have many therapeutic properties and shown wider effect against abnormalities like inflammation, cancer, hypertension, diuresis, and pain (Sarita, and Singh. 2016; Nithiyanantham et al., 2019).

Millet are source of dietary fiber because its seed coat have components like pectin, cellulose, and hemicelluloses which are not easily hydrolyzed by digestive enzymes (Chethan and Malleshi, 2007). The presence of dietary fiber in seed coat of millet grains are beneficial to human health which affects several metabolic and digestive processes, such as effects on glucose absorption and cholesterol levels (Johnson, et al., 2019). Kodo millet and little millet are also reported to have $37 \%$ to $38 \%$ of dietary fiber, which is the highest among the cereals and though low in fat- content, it is high in polyunsaturated fatty acids (PUFA) (Malleshi and Hadimani 1993; Antony et al. 1996).

Kodo millet has the highest level of free radical activity (DPPH) followed by sorghum and finger millet (Deshpande et al., 2015). Kodo millet has the highest free radical (DPPH) quenching activity followed by great millet (sorghum) and finger millet (Hegde and Chandra, 2005). Due to elevated antioxidant content it protects against oxidative stress and retaining glucose concentrations in type-2 diabetes. Dietary enhancement with phenolic acid-rich food products has been shown to impart antimutagenic, antiglycemic and antioxidant characteristics, which can be utilized in the development of health products (Friedman, 1997; Shobana et al., 2007)). In addition, millets are gluten-free, easy to digest and are a great source of antioxidants and might have anti-carcinogenic properties (Dykes and Rooney, 2006).

\section{Medicinal Values of Kodo millet}

\section{Millets for diabetes}

Lower incidences of diabetes in the milletconsuming population have been recorded. Millet contain phenolics such as alpha glucosidase, pancreatic amylase by partly inhibiting the enzymatic hydrolysis of complicated carbohydrates reduces postprandial hyperglycemia (Shobana et al., 2009). Inhibitors such as aldose reductase prevent sorbital accumulation and decrease the likelihood of cataract diseases caused by diabetes (Chethan and Malleshi, 2007).

\section{Millets and aging}

The diabetes and aging is mainly attributed due to the chemical reaction between the amino group of proteins and the aldehyde reduction group of sugars which is known as non-enzymatic glycosylation. Millets including Kodo millet are rich in antioxidants and phenolics such as phytates, phenols, and tannins that may contribute to important antioxidant activity in health, aging, and metabolic syndrome (Hegde et al., 2005).

\section{Millets against cancer and celiac disease}

Millets are rich in phenolic acids, tannins and phytes that behave as "anti-nutrients." These anti-nutrients, however, decrease risk of colon and breast cancer in animal. Millet contains phenolics that have been shown to be efficient in preventing cancer initiation and in vitro development (Chandrasekara et al., 2010). Together with the growing amount of individuals suffering from celiac disease, the general growing demand for novel, tasty and 
"healthy" foods has provided birth to a fresh industry of cereal products produced from grains other than wheat and rye. Celiac disease is an immune-mediated enteropathy that is caused by gluten intake in genetically prone people. Since millets are gluten-free, however, they have significant potential in foods and drinks that may be appropriate for people with celiac illness (Taylor, 2006; Ezeogu et al., 2008). Therefore, millet grains and their functions have the ability to be helpful in the prevention of cancer and in the production of celiac food products.

\section{Millets for cardiovascular disease}

Obesity, smoking, unhealthy nutrition and physical inactivity boost the risk of heart attack and stroke. Most nations in the globe are facing elevated and rising cardiovascular disease rates. Millets have higher amount of free radical scavenging activity which decreases the risk of cardiovascular diseases (Hegde and Chandra, 2005).

\section{Traditional use of Kodo millet}

Millets are rich in vitamins, minerals, phytochemicals and amino acid containing sulphur, and are therefore referred to as nutricereals. In addition, millets are recommended for celiac patients as they do not contain gluten (Chandrasekara and Shahidi, 2010). Cereals especially millet based foods and beverages are popular throughout the world and are still important part of diet in most of African countries (Obilana and Manyasa, 2002; Amadou et al., 2011). Millet and its flour is generally used to make porridge with milk and beverages. Millet is staple food in many developing countries of Asia and Africa in which millet is grown abundantly. Millets are used to prepare traditional foods and beverages like idli, dosa, papad, chakli, porridges, breads, infant formulae and snacks (Chandrasekara and Shahidi, 2011). In
Maharashtra state flat thin cakes called Roti are often made from sorghum/millet flour and used as the basis for meals. It is possible to incorporate $50-75 \%$ barnyard millet flour in preparation of rotis, idlies, dosa, chakli (Veena et al., 2004); idli, pakora, vedai, adai and sweet halwa, kolukattai from finger millet; navane sampali, huggi, burfi or kabab from foxtail millet; and samai dosa, porridge, paddu and paysamfrom little millet as traditional recipes in different millet growing states in India (Jayabhae et al., 2014). Kodo millet is an important food crop for vast sections of the tribal community in Central India. The people in Himalayan foothills use millet as a cereal, in soups, and for making dense, whole grain bread called Chapatti. One of the popular alcoholic fermented beverage used in Darjeeling hills and Sikkim in India known as 'Kodo ko jaanr' is manufactured by using dry seeds of finger millet. Chhang is also a fermented finger millet beverage popular in Ladakh region in India. Koozh is another fermented beverage made with pearl or finger millet flour and rice, and consumed by ethnic communities in Tamil Nadu (Ilango and Antony, 2014). Although many traditional foods can be prepared in the domestic household, but limited large-scale commercial use of millet discourages the farmers to grow millets (Subramanian and Viswanathan, 2003). Therefore, there is an emerging need for the world to produce industrial products using millets.

\section{Development of Value Added products Using Kodo millet}

Millet is staple food in many parts of world. Millet grains are considered suitable for processing can be performed at domestic as well industrial level (Obilana and Manyasa, 2002; Millets, 1995). Due to its prospective health advantages and the fight against multiple illnesses, millet grains are now getting more interest by food technologists 
and nutritionists (Shahidi and Chandrasekara, 2013). In many developed countries, millets are underutilized. In developing nations, there is enormous potential for processing millet grains into value-added foods and drinks. Therefore, many countries of world started and expedited research to study and develop advance processing technologies at industrial level for improved nutritive value and functionality to fulfill the customer satisfaction.

\section{Blended flour}

Millets are nutritionally better than cereals but their utilization is still not explored properly, their utilization can be increased by blending them with wheat flour after suitable processing (Singh and Raghuvanshi, 2012). When millets flour added in other products, there would be changes in physico-chemical, nutritive value and functional characteristics of blended product (Jaybhaye et al., 2014). There is lot of convenience food products including extruded products are consumed widely in developed countries. Extruded products prepared by using millets have higher nutritive value in comparison to weaning foods of acceptable quality (Almeida-Dominguez et al., 1993). Balasubramanian et al., 2012 reported about low cost snacks production using pearl millet. A lot of researcher have tried to prepare composite millet flours by substituting generally used cereal flours to manufacture various food products like ready-to-use foods, pasta preparation etc. This approach is very convenient technique to get nutritionally improved with increased functionality.

\section{Baked products}

The popularity of bakery products are increasing day by day worldwide due to its taste variation, low cost, varying texture profile, long shelf life and attractive packaging options (Bunkar et al. 2012). The use of millets in bakery products will not only be superior in terms of fibre content, micronutrients but also create a good potential for millets to enter in the bakery world for series of value added products (Verma and Patel, 2013). These are mostly prepared from the wheat flour but efforts are being made to replace few portion of it with millets in order to provide an alternative and reduce over dependence on wheat and make gluten free bread. Finger millet and foxtail millet flour can be incorporated in bakery items like biscuits, nan-khatai, chocolate, cheese, cakes, muffins, etc. Research findings have revealed that substitution of $40 \%$ wheat flour with finger millet flour in baked products like cake and biscuits is possible (Begum et al., 2003; Yenagi et al., 2013). The chocolate cup cake, gel cake, masala cake, carrot cake, soup sticks, rusk and muffins prepared with finger millet have good appearance, texture, flavour and overall acceptability scores. Attempts have been made to improve the nutritional quality of cakes with respect to the minerals and fibre content by supplementing with malted finger millet flour (Desai et al., 2010)

\section{Fermented products}

Fermented foods like Dosa and Idli are the most commonly used fermented foods in South India. The cereal based fermented foods are very popular and widely used throughout the world because of its significance as human food (Mugocha et al., 2000; Gotcheva et al., 2001). Millet based fermented products also used due to its benefits like, in vitro protein digestibility and decreases the levels of anti-nutrients in food grain (Chavan and Kadam, 1989; Begum et al., 2003; Verma and Patel, 2013). Fermentation of the ground germinated pearl millet grains leads to chemical changes in its composition and high protein digestibility is observed which accounts for 90\% (Ahmed et 
al., 2009). Pearl millet was fermented by inoculating S. diacetylactis, $S$. cerevisiae, $L$. brevis and L. fermentum which increased the starch digestibility of flour significantly (Khetarpaul et al., 1990). The various recipes of acceptable quality were prepared using naturally and mixed fermented pearl millet flour including cutlets, weaning mixtures, vermicelli and biscuits. Based on scientific literature, it can be suggested that production of millet based fermented products including Kodo millet can be a profit making formula using fermentation and enzymatic hydrolysis processes to enhance nutritive value and decrease of anti-nutritive factors.

\section{Puffed/popped and flaked millets}

Use of cereal based puffed product is an old traditional practice of cooking grains to be used as snack or breakfast cereal either plain or with some spices/salt/sweeteners (Jaybhaye et al., 2014). The cereal processing technologies was effectively applied to foxtail millet to prepared RTE or ready to use products in the form of flaked, extruded and roller dried decorticated and popped grains by subjecting native grains $(12 \% \mathrm{mc})$ to HTST treatment at $230+/-5^{\circ} \mathrm{C}$ (Ilango, and Antony, 2014). Jaybhyae and Srivastav (2010a; 2010b) prepared ready-to-eat (RTE) barnyard millet based snack food by forming thin rectangular shaped, steam cooked cold extrudate (cut pieces of dough) samples and puffing them with HTST puffing process.

\section{Extruded products}

Extruded products cooked at high temperature with less holding time which leads to gelatinization of starch and denaturation of protein. This process improves digestibility and causes inactivation of anti-nutrient factors (Awika and Rooney, 2004). Extrusion process have many advantage like improved and consistent quality, high production, variety in products, enhanced in vitro digestibility of proteins (Dahlin and Lorenz, 1993). This process improves the availability of iron in extruded foods (Cisse et al., 1998). Millet based extruded snack foods are prepared using twin-screw extruder from Kodo milletchickpea flour blend (70:30) (Geetha et al., 2014); pearl millet, finger millet and soybean flour blend (Balasubramanian et al., 2012) or ragi, sorghum, soy and rice (42.03, 14.95, 12.97 and $30 \%$ ) flour blend (Seth and Rajamanickam, 2012) with desired quality. Devi and Narayanasamy (2013) explored the possibility of preparation of composite millets milk powder with the combination of finger millet and pearl millet to prepare RTC extruded product from composite of millet powder and maida (50:50) within the acceptable range in terms of nutrient content, color, texture and cooking quality and sensory characteristics

\section{Healthy and functional foods}

Millets have received attention for their potential role as functional foods due to health promoting phytochemicals. Small millets are important coarse grains and rich in nutrients. Epidemiological studies reflect that persons on millet based diet suffer less from degenerative diseases such as heart diseases, diabetics, hypertension, etc. (Jaybhaye et al., 2014). Millets and millet based products are the safe food for the patients having celiac disease and gluten allergy due to its characteristic of not producing acids and antiallergic properties (Saleh et al., 2013).The various healthy products were prepared blending millets including Kodo millet with other cereals like low glycaemic index biscuits (Srivastava and Singh, 2003), diabetic food formulations (Shobana et al. 2007), roti, upma and idli with low glycaemic index (Thakkar and Kapoor, 2007). However, no such product is commercially produced and reported which is entirely based on millet. 


\section{Effect of processing on nutritional quality} of Kodo millet

Kodo millets contain higher amounts of polyphenols, phosphorous, antioxidants, and phytic acids. These anti-nutrients make complexes of micronutrients like calcium and zinc, which reduce their solubility and bioavailability. Techniques like soaking, cooking and fermentation of millet-based foods reduce tannin and phytate levels, which enhance availability of amino acids and minerals and also improve digestibility of protein and starch. Chandrasekher et al. (1981) studied millet varieties for preventive action against human salivary amylase and discovered no detectable activity in Kodo millet verities. The antioxidant activity of Kodo millets decreases when the whole grain is dehulled and cooked. Hegde and Chandra
(2005) show that Kodo millet has a higher free radical scavenging property as compared to other millets such as finger millet, small millet, foxtail millet, barnyard millet and large millet. It was also seen that the activity was also decreased by fractionation of husk and endosperm of Kodo millet. Chandrasekara et al. (2012) indicates that the antioxidant activity of whole Kodo decreased from 32.4 to 6.86 in dehulled one, while only 6.06 in dehulled boiled Kodo millet. Approximately 112 ( $\mu$ mol ferulic acid equ/g defatted meal) are also included in the bran. Annor et al. (2013), study revealed that the anticipated glycemic index (AGI) of whole Kodo millet starch is lower than that of rice starch. Furthermore, the entire Kodo grain has decreased starch and AGI digestibility than the decorated grains (Yadav et al., 2013).

Table.1 Nutritional composition of Kodo millet

\begin{tabular}{|l|c|}
\hline Nutrient & Quantity $\mathbf{( 1 0 0 g m})$ \\
\hline Moisture & $11.6 \mathrm{gm}$ \\
\hline Protein & $10.6 \mathrm{gm}$ \\
\hline Fat & $4.2 \mathrm{gm}$ \\
\hline Fiber & $10.2 \mathrm{gm}$ \\
\hline Ash & $2.95 \mathrm{gm}$ \\
\hline Calorific value & $346 \mathrm{kcal}$ \\
\hline Carbohydrate & $59.2 \mathrm{gm}$ \\
\hline Minerals & $4.4 \mathrm{gm}$ \\
\hline Calcium & $27 \mathrm{mg}$ \\
\hline Phosphorus & $188 \mathrm{mg}$ \\
\hline Iron & $0.5 \mathrm{mg}$ \\
\hline Riboflavin & $0.09 \mathrm{mg}$ \\
\hline Niacin & $2.0 \mathrm{mg}$ \\
\hline
\end{tabular}

(Hadimani and Malleshi, 1993; Millets, 1995; Vijay et al., 2013; Devi, et al., 2014)

In conclusion, millets have been used traditionally as cereal since long back due to nutritional and health promoting properties. Millets including Kodo millet have great potential as raw material for use in commercial products. Although the millets have equivalent health benefits and nutrition value to other major cereals like rice, wheat and maize but the limited technological advances work out to enhance its acceptability in consumers in terms of quality, nutrition and functionality. The present review includes scientific studies done, till date, for the enhancements of processing 
technologies, health benefits of millets with special reference to Kodo millet. It is necessary to shift processing and equipments from traditional to modern methods and optimizes processing conditions to make quality products that are affordable. The improved efficiency in post-harvesting and value addition expertise has created various opportunities for the food processing industry to manufacture quality millet based products which have wider consumer acceptability. So, there is very good prospect to do thorough research for better quality millet products that should be health promoting, tasty, long shelf life and attractive color and appearance and affordable for all income group consumers.

\section{References}

Adekunle, A. A. (2012). Agricultural innovation in sub-saharan africa: experiences from multiple stakeholder approaches. Forum for Agricultural Research in Africa, Ghana. ISBN 9789988- 8373-2-4.

Ahmed, A. I. Abdalla, A. A. and Tinay, A. E. (2009). Effect of traditional processing on chemical composition and mineral content of two cultivars of pearl millet (Pennisetum glaucum) Journal of Applied Sciences Research 5(12):22712276.

Almeida-Dominguez, H. D., Gomez, M. H., Serna-Saldivar, S. O., Waniska, R. D., Rooney, L. W. and Lusas, E. W. (1993). Extrusion Cooking of Pearl Millet for Production of Millet-Cowpea Weaning Foods'. Cereal Chem, 70(2), 214-219.

Amadou, I., Mahamadou E. Gounga and GuoWei Le. (2013). Millets: Nutritional composition, some health benefits and processing - A Review. Emir. J. Food Agric. 2013. 25 (7): 501-508.

Annor, G. A., Tyl, C. E., M, M. F. and Ragaee, S. (2017). Why do millets have slower starch and protein digestibility than other cereals? Trends in Food Science and Technology 66.

Antony, U., Sripriya, G. and Chandra, T. S. (1996). Effect of fermentation on the primary nutrients in finger millet (Eleusine coracana). Journal of Agriculture and Food Chemistry, 44: 2616-2618.

Arendt, E. and Dal Bello, F. Gluten-Free Cereal Products and Beverages. (2011). Academic Press: Cambridge, MA, USA.

Awika, J. M. and Rooney, L.W. (2004). Sorghum Phytochemicals and Their Potential Impact on Human Health. Phytochemistry, 65, 1199-1221.

Badau, M,. Nkama, H. I. and Jideani, I. A. (2005). Phytic acid content and hydrochloric acid extractability of minerals in pearl millet as affected by germination time and cultivar. Food Chem. 92(3):425-435.

Balasubramanian, S. (2013). Possessing of Millets. Paper Presented National Seminar on Recent Advances In Processing, Utilization and Nutritional Impact of Small Millets. Madurai.

Balasubramanian, S., Singh, K. K., Patil, R. T., and Onkar, K. K. (2012). Quality evaluation of millet-soy blended extrudates formulated through linear programming. Journal of food science and technology, 49(4), 450-458.

Baltensperger, D. D. (1996). Foxtail and Kodo millet. Progress in New Crops. J. Janic, ed. ASHS Press, Alexandria, VA.

Bellato, S., Ciccoritti, R., Del Frate, V., Sgrulletta, D. and Carbone, K. (2013). Influence of genotype and environment on the content of 5-n alkylresorcinols, total phenols and on the antiradical activity of whole durum wheat grains. Journal of Cereal Science, 57(2), 162-169.

Bhat, S., Nandini. C., Tippeswamy and Prabhakar (2017). Significance of Small 
Millets In Nutrition And Health -A Review, AICRP On Small Millets, Asian Journal of Dairy and Food Research 37(1): 35-40.

Begum, J. M., Vijayakumari, Begum, S., Pandy, A., Shivaleela, H. and Meenakumari (2003). Nutritional composition and sensory profile of baked products from finger millet. In: Recent Trends in Millet Processing and Utilization, CCS Hisar Agricultural University, Hisar, India, pp 82-87.

Bunkar, D. S., Jha, A., Mahajan, A. and Unnikrishnan, V. S. (2012). Kinetics of changes in shelf life parameters during storage of pearl millet kheer mix and development of a shelf life prediction model. Journal of Food Sciences and Technology, 51(12): 3740-3748.

Chandrasekher, G., Raju, D. S. and Pattabiraman, T. N. (1981). Natural plant enzyme inhibitors. $\alpha$ - amylase inhibitors in millets. Volume 32, Issue1, Pages 9-16.

Chandrasekara, A. and Shahidi, F. (2010). Content of Insoluble Bound Phenolics In Millets and Their Contribution To Antioxidant Capacity. Journal of Agricultural Food Chemistry, 58(11): 6706-6714.

Chandrasekara, A. and Shahidi, F. (2011). Inhibitory activities of soluble and bound millet seed phenolics on free radicals and reactive oxygen species. Journal of Agricultural and Food Chemistry, 59(1), 428-436.

Chandel, U., and Mankotia, B. S. (2014). Combining Ability in Local and Cimmyt In Bred Lines of Maize (Zea mays L.) for Grain Yield and Yield Components Using Line $\mathrm{x}$ Tester Analysis. SABRAO Journal of Breeding and Genetics, 46(2).

Chavan, J. K., Kadam, S. S. and Beuchat, L. R. (1989). Nutritional improvement of cereals by sprouting. Critical Reviews in Food Science and Nutrition, 28(5), 401-437.

Chetan, S., and Malleshi, N. (2007). Finger Millet Polyphenols: Characterization and Their Nutraceutical Potential, American Journal of Food Technology 2(7): 582.

Chinchole, M., Pathak, R. K., Singh, U. M., and Kumar, A. (2017). Molecular characterization of EcCIPK24 gene of finger millet (Eleusine coracana) for investigating its regulatory role in calcium transport. 3 Biotech, 7, 267.

Cisse, D., Guiro, A. T., Diaham, B., Souane, M., Doumbouya, N. T. S., and Wade, S. (1998). Effect of food processing on iron availability of African pearl millet weaning foods. International journal of food sciences and nutrition, 49(5), 375381.

Crawford, G. W., and G.-A. Lee. 2003. Agricultural origins in Korea. Antiquity 77(295):87-95.

Dahlin, K. and Lorenz, K. (1993). Protein digestibility of extruded cereal grains. Journal of Food Chemistry 48: 13-18.

Desai, A. D., Kulkarni, S. S., Sahoo, A. K., Ranveer, R. C., and Dandge, P. B. (2010). Effect of supplementation of malted ragi flour on the nutritional and sensorial quality characteristics of cake. Advance Journal of Food Science and Technology, 2(1), 67-71.

Deshpande, S. S., Mohapatra, D., Tripathi. M. K., and Sadvatha R. H. (2015). Kodo millet-Nutritional Value and Utilization in Indian Foods, ICAR-Central Institute of Agricultural Engineering, Nabibagh, Journal of Grain Processing and Storage Vol 2.

Devi, M. P. and Narayanasamy, S. (2013). Extraction and dehydration of millet milk powder for formulation of extruded product. IOSR Journal of Environmental Science, Toxicology and Food Technology, 7(1): 63-70. 
Devi, G. S., Palanimuthu, V., and Arun K. P., (2014). Studies on development and storage of Kodo millet based porrdige. International Journal of Processing and Post Harvest Technology, 5(1): 33-40.

Devi, P. B., Vijayabharathi, R., Sathyabama, S., Malleshi, N. G. and Priyadarisini, V. B. (2011). Health benefits of finger millet (Eleusine coracana L.) polyphenols and dietary fiber: a review. J. Food Sci. Technol. DOI: 10.1007/s13197-011-0584-9.

Dykes, L., and Rooney, L. W. (2006). Sorghum and millet phenols and antioxidants. Journal of cereal science, 44(3), 236-251.

Ezeogu, L. I., Duodu, K. G., Emmambux, M. N., and Taylor, J. R. (2008). Influence of cooking conditions on the protein matrix of sorghum and maize endosperm flours. Cereal Chemistry, 85(3), 397-402.

Friedman, M. (1997). Chemistry, biochemistry, and dietary role of potato polyphenols. A review. Journal of agricultural and food chemistry, 45(5), 1523-1540.

Geetha R, Mishra HN, Srivastav, P. P. (2014). Twin screw extrusion of kodo milletchickpea blend: process parameter optimization, physico-chemical and functional properties. J Food Sci Technol. 51(11):3144-53.

Gopalan, C., and Shastri, B. (2009). Nutritive Value of Indian Foods, Nutritional Institute of Nutrition, Indian Council of Medical Research, Hyderabad, India. 99.

Gotcheva, V., Pandiella, S. S., Angelov, A. and Roshkova, Z. (2001). Monitoring the fermentation of the traditional Bulgarian beverage Boza. International Journal of Food Science and Technology 36(2):129-134.

Hadimani, Na. Ali, Sz. and Malleshi, Ng (1995). Physico-Chemical Composition and Processing Characteristics of Pearl Millet Varieties. Journal of Food Science and Technology 32:193-198.

Hadimani, Na. and Malleshi, Ng. (1993). Studies on Milling, Physicochemical Properties, Nutrient Composition and Dietary Fiber Content of Millets. Journal of Food Science and Technology 30:193-198.

Hegde, P. S. and Chandra, T. S. (2005). ESR spectroscopic study reveals higher free radical quenching potential in kodo millet (Paspalum scrobiculatum) compared to other millets. Food Chemistry, 92(1), 177-182.

Hegde, P. S., Rajasekaran, N. S. and Chandra, T. 2005. Effects of antioxidant properties of millet species on oxidative stress and glycemic status in alloxaninduced rats. Nutrition Research 25(12):1109-1120

House, L. R., Osmanzai, M., Gomez, M. I., Monyo, E. S., and Gupta, S. C. (1995). Agronomic principles.

Hulse, J. H., Laing, E. M. and Pearson, O. E. (1980). Sorghum and the Millets: Their Composition and Nutritive Value; Academic Press: Cambridge, MA, USA.

ICRISAT, (2017). Small millets Retrieved from http://www.icrisat.org/homepage

Ilango, S., and Antony, U. (2014). Assessment of the microbiological quality of koozh, a fermented millet beverage. African Journal of Microbiology Research, 8(3), 308-312.

Jain, S., Dabur, R.S., Bishnoi, S. and Jitender. (2016). Development of milk based finger millet (Ragi) porridge: effects of malting of finger millet on compositional attributes. Haryana Veterinarian, 55(2):155-159.

Jaybhaye, R. V., Pardeshi, I. L., Vengaiah, P. C. and Srivastav, P. P. (2014). Processing and Technology for Millet Based Food Products: A Review. 
Journal of ready to eat food. 1 (2), 3248.

Jaybhaye, R. V. and Srivastav, P. P. (2010a). Oven toasting of barnyard millet based ready-to-eat (RTE) snacks: Process parameter optimization and sensory evaluation. Proceedings of International Conference on 'Food Technology Edition II' from 30 - 31 October, 2010 at IICPT, Tanajavur (T.N.).

Jaybhaye, R. V. and Srivastav, P. P. (2010b). Optimization of process parameters for development of millet based puffed snack food. International Conference on 'Food and Health' from 10-12th November, 2010 at Dublin, Ireland.

Johnson, M., Deshpande, S., Vetriventhan, M., Upadhyaya, H. D., and Wallace, J. G. (2019). Genome- Wide Population Structure Analyses of Three Minor Millets: Kodo Millet, Little Millet, and Proso Millet. The Plant Genome, 12(3), 1-9.

Khetarpaul, N. and Chauhan, B. M. (1990). Fermentation of pearl millet flour with yeasts and lactobacilli: in vitro digestibility and utilisation of fermented flour for weaning mixtures. Plant Foods Hum Nutr. Jul;40(3):167-73.

Liang, S., G. Yang and Y. Ma. (2010). Chemical characteristics and fatty acid profile of foxtail millet bran oil. J. Am. Oil Chem. Soc. 87: 63- 67.

Malathi, D., Thilagavathi, T., and Sindhumathi, G. (2012). Traditional Recipes from Kodo millet, Revalorizing small millets. "Enhancing the food and nutritional security of women and children in rain fed regions of South Asia using underutilized species". Post Harvest Technology Centre Agricultural Engineering College and Research Institute Tamil Nadu Agricultural University.

Malleshi, N. G. and Hadimani, N. A. (1993). Nutritional and technological characteristics of small millets and preparation of value added products from them. In: Advances in Small Millets. Oxford IBH Publishing Co. Pvt. Ltd., New Delhi, pp: 271-287.

Mugocha, P. T., Taylor, J. R. N. and Bester, B. H. (2000). Fermentation of a composite finger millet dairy beverage. World Journal of Microbiology and biotechnology. 16:341-344.

Millets: Chemistry and Technology; American Association for Cereal Chemist: St. Paul, MN, USA, 1995; pp. 27-67.

Nithiyanantham, S, Kalaiselvi, P., Mahomoodally, M. F., Gokhan, Z., Abirami, A. and Gopalakrishnan, S. (2019). Nutritional and functional roles of millets-A review. Journal of Food Biochemistry, pp, 1-10.

Obilana, A. B. (2003). Overview: importance of millets in Africa. World (all cultivated millet species). 38 .

Obilana, A. B. and Manyasa, E. (2002). Millets. In: Pseudocereals and Less Common Cereals. Springer, Berlin, Heidelberg.

Okwudili, U. H., Gyebi, D. K., and Obiefuna, J. A. I. (2017). Finger millet bioactive compounds, bioaccessibility, and potential health effects-a review. Czech Journal of Food Sciences, 35(1), 7-17.

Pradeep, P. M. and Sreerama, Y. N. (2015). Impact of processing on the phenolic profiles of small millets: Evaluation of their antioxidant and enzyme inhibitory properties associated with hyperglycemia. Food Chemistry, 169 (2015), pp. 455-463

Pradeep, P. M., and Sreerama, Y. N. (2018). Phenolic antioxidants of foxtail and little millet cultivars and their inhibitory effects on $\alpha$-amylase and $\alpha$-glucosidase activities. Food Chemistry, 247, 46-55.

Parvathy, K. and Thayumanavan, B. (1995). Homologies between prolamins of 
different minor millets. Plant Foods Hum Nutr 48: 119-126.

Ravi, S. B. (2004). Neglected millets that save the poor from starvation. LEISA India, $6,1-8$.

Ravindran, G (1992). Seed proteins of millets: amino acid composition, proteinase inhibitors and in vitro digestibility. Food Chemistry, 44(1): 13-17.

Saleh, A.S., Zhang, Q., Chen, J. and Shen, Q. (2013), Millet Grains: Nutritional Quality, Processing, and Potential Health Benefits. Comprehensive Reviews in Food Science and Food Safety, 12: 281-295.

Sarita, E. S., and Singh, E. (2016). Potential of millets: nutrients composition and health benefits. Journal of Scientific and Innovative Research, 5(2), 46-50.

Saxena R., Vanga, S K., Wang, J, Orsat, V and Raghavan, V. (2018). Millets for Food Security in the Context of Climate Change: A Review. Sustainability, 10: $1-31$.

Seth, D. and Rajamanickam, G. (2012) Development of extruded snacks using soy, sorghum, millet and rice blend $-\mathrm{A}$ response surface methodology approach. Volume 47, Issue7 Pages 1526-1531

Shahidi, F. and Chandrasekara, A. (2013). Millet grain phenolics and their role in disease risk reduction and health promotion: A review, Journal of Functional Foods, Volume 5, Issue 2, Pages 570-581.

Shobana S, Singh, R. U., Malleshi, N. G. and Ali, S. Z. (2007). Glycemic response of rice, wheat and finger millet based diabetic food formulations in normoglycemic subjects. International Journal Food Science Nutrition, 58(5): 363-372.

Shobana, S., Sreerama, Y. N., and Malleshi, N. G. (2009). Composition and enzyme inhibitory properties of finger millet
(Eleusine coracana L.) seed coat phenolics: Mode of inhibition of $\alpha$ glucosidase and pancreatic amylase. Food Chemistry, 115(4), 1268-1273.

Sindhu, S. C. and Khetarpaul, N. (2001). Probiotics: Nutritional and health benefits. Life Science Reporter 3(1and2): 1-10.

Singh, P. and Raghuvanshi, R. (2012). Finger Millet for Food and Nutritional Security. African Journal of Food Science, 6(4): 77-84.

Srivastava, S. and Singh, G. (2003). Processing of millets for value addition and development of health foods. In: Recent Trends in Millet Processing and Utilization, Hisar, India: Chaudhary Charan Singh Hisar Agril. University, pp.13-18.

Sudharshana, L., Monteiro, P.V., and Ramachandra, G. (1988). Studies on the proteins of Kodo millet (Paspalum scrobiculatum). Journal of the Science of Food and Agriculture, 42(4): 315323.

Subramanian, S., and Viswanathan, R. (2003). Thermal properties of minor millet grains and flours. Biosystems Engineering, 84(3), 289-296.

Taylor, S. E. (2006). Tend and befriend: Biobehavioral bases of affiliation under stress. Current directions in psychological science, 15(6), 273-277.

Thakkar, R. and Kapoor, R. (2007). Enrichment of rice and finger millet based preparations with gum acacia and their effects on glycemic response in non-insulin dependent diabetic subjects. Journal of Food Science and Technology, 44(2): 183-185.

Verma, V. and Patel, S. (2017). Value Added Products from Nutri-cereals: Finger Millet (Eleusine Coracana). Emirates Journal of Food and Agriculture, Vol. 25, no. 3, Nov., p. 169/176, 
Veena, B. Chimmad, B. V., Naik, R. K. and Shantakumar, G., 2004, Development of barnyard millet based traditional foods. Karnataka J. Agril. Sci., 17 (3): 522527.

Vijaykumar, T. P., Shetty, H. S. and Urooj, A. (2013). Physico chemical and functional characteristics of processed Kodo millet flour. Paper presented National Seminar on Recent Advances in processing, utilization and nutritional impact of small millets. MaduraiSymposium, Thamukkam Grounds, Madurai, 13 September, 2013. Yadav, N., Chaudhary, K., Singh, A. and Gupta, A. (2013). Evaluation of hypoglycemic properties of Kodo millet based food products in healthy subjects. Journal of Pharmacy, 3(2):14-20.

Yang L, Chen J, Xu T, Qiu W, Zhang Y, Zhang L, Xu F, Liu H. (2011). Rice protein extracted by different methods affects cholesterol metabolism in rats due to its lower digestibility. Int $\mathrm{J}$ Mol Sci.;12(11):7594-608.

Yenagi, N., Joshi, R., Byadgi, S. and Josna, B. (2013). A Handbook for School Children: Importance of Millets in Daily Diets for Food and Nutrition Security. University of Agricultural Sciences, Dharwad, India, p, 1-24.

\section{How to cite this article:}

Durga Shankar Bunkar, S K Goyal, Kamalesh Kumar Meena and Virendra Kamalvanshi. 2021. Nutritional, Functional Role of Kodo Millet and its Processing: A Review. Int.J.Curr.Microbiol.App.Sci. 10(01): 1972-1985. doi: https://doi.org/10.20546/ijcmas.2021.1001.229 